\title{
Echocardiography monitoring for diazoxide induced pericardial effusion
}

\author{
Bindu Avatapalle, ${ }^{1}$ Indraneel Banerjee, ${ }^{2}$ Nilima Malaiya, ${ }^{3}$ Raja Padidela ${ }^{1}$ \\ ${ }^{1}$ Department of Paediatric Endocrinology, Manchester Children's Hospital, Manchester, UK; \\ 2Department of Paediatric Endocrinology, University of Manchester and Manchester Children's Hospital, Manchester, UK; \\ ${ }^{3}$ Department of Paediatric Cardiology, Manchester Children's Hospital, Manchester, UK
}

Correspondence to Dr Raja Padidela, raja.padidela@cmft.nhs.uk

\section{DESCRIPTION}

A 3-year-old boy with Down's syndrome with no underlying cardiac anomalies presented with hypoglycaemia due to congenital hyperinsulinism (CHI). He received treatment
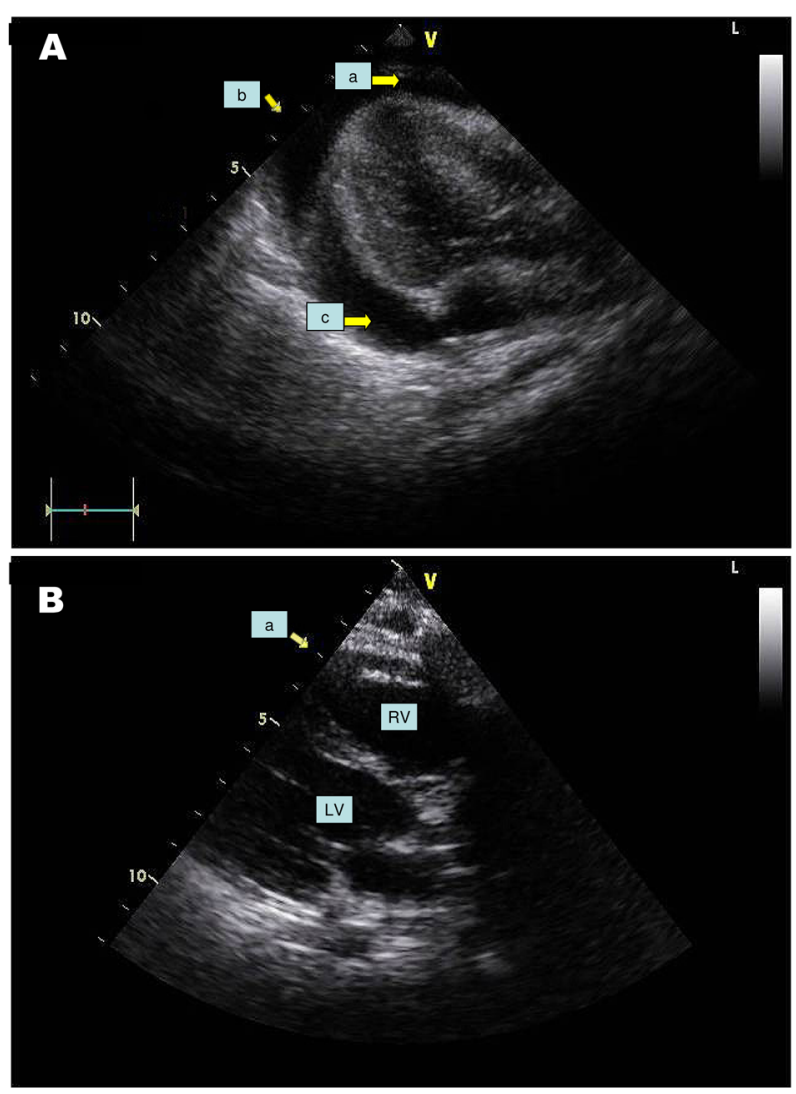

Figure 1 (A) Long axis view of the heart showing $0.4 \mathrm{~cm}$ pericardial effusion anteriorly (a), $1 \mathrm{~cm}$ pericardial effusion at the apex (b) and $1.4 \mathrm{~cm}$ pericardial effusion posteriorly (c). (B) Long axis view of the heart showing $0.5 \mathrm{~cm}$ pericardial effusion (a), right ventricular cavity (RV) and left ventricular cavity (LV). with oral diazoxide (Proglycem) $(10 \mathrm{mg} / \mathrm{kg} /$ day), along with the diuretic chlorothiazide, which ensured glycaemic stability. However, a large pericardial effusion (figure 1A) requiring drainage was noted within a month. Diazoxide was discontinued and second line treatment with octre-

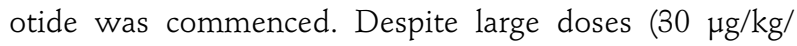
day), glycaemic control remained unsatisfactory. A further trial of diazoxide was undertaken, pending a decision for subtotal pancreatectomy. Diazoxide was introduced at 1 $\mathrm{mg} / \mathrm{kg} /$ day and increased to $4 \mathrm{mg} / \mathrm{kg} /$ day (low dose) by 2 weeks with satisfactory glycaemic control. However, serial weekly echocardiography detected minimal pericardial effusion (figure 1B) without overt features of cardiovascular instability. Withdrawal of diazoxide therapy led to resolution of the pericardial effusion. Euglycaemia was achieved by subtotal pancreatectomy. Diazoxide is commonly used as first line treatment for CHI. Diazoxide can cause fluid retention ${ }^{1}$ and cardiovascular adverse events. ${ }^{2}$ Heart failure in a child with underlying cardiac anomalies has been observed with high doses $(15 \mathrm{mg} / \mathrm{kg} /$ day) of diazoxide. ${ }^{3}$ However, it is not recognised that diazoxide in low doses can cause pericardial effusion, particularly in the absence of underlying cardiac anomalies. In this case report, we have observed pericardial effusion at both high and low doses of diazoxide in a child with a structurally normal heart. Therefore, we would recommend meticulous cardiovascular monitoring in children commenced on diazoxide for $\mathrm{CHI}$ to prevent serious haemodynamic instability from developing pericardial effusions.

Competing interests None.

Patient consent Obtained.

\section{REFERENCES}

1. Hussain K. Diagnosis and management of hyperinsulinaemic hypoglycaemia of infancy. Horm Res 2008;69:2-13.

2. Yildizdas D, Erdem S, Küçükosmanoglu 0, et al. Pulmonary hypertension, heart failure and neutropenia due to diazoxide therapy. Adv Ther 2008;25:515-9.

3. Silvani $\mathbf{P}$, Camporesi A, Mandelli A, et al. A case of severe diazoxide toxicity. Paediatr Anaesth 2004;14:607-9. 


\section{BMJ Case Reports}

This pdf has been created automatically from the final edited text and images.

Copyright 2012 BMJ Publishing Group. All rights reserved. For permission to reuse any of this content visit http://group.bmj.com/group/rights-licensing/permissions.

BMJ Case Report Fellows may re-use this article for personal use and teaching without any further permission.

Please cite this article as follows (you will need to access the article online to obtain the date of publication).

Avatapalle B, Banerjee I, Malaiya N, Padidela R. Echocardiography monitoring for diazoxide induced pericardial effusion. BMJ Case Reports 2012;10.1136/bcr.03.2012.6110, Published XXX

Become a Fellow of BMJ Case Reports today and you can:

- Submit as many cases as you like

- Enjoy fast sympathetic peer review and rapid publication of accepted articles

- Access all the published articles

- Re-use any of the published material for personal use and teaching without further permission

For information on Institutional Fellowships contact consortiasales@bmjgroup.com

Visit casereports.bmj.com for more articles like this and to become a Fellow

Keep up to date with all published cases by signing up for an alert (all we need is your email address) http://casereports.bmj.com/cgi/alerts/etoc 